\title{
Effect of manganese and nitrogen fertilization on the content of some essential micronutrients and composition of fatty acids in winter wheat grain
}

\author{
Arkadiusz Stepien $^{1 *}$, Katarzyna Wojtkowiak ${ }^{2}$, Renata Pietrzak-Fiecko ${ }^{3}$, Marta Zalewska ${ }^{1}$, \\ and Malgorzata Grzywinska-Rapca ${ }^{4}$
}

${ }^{1}$ University of Warmia and Mazury in Olsztyn, Faculty of Environmental Management and Agriculture, Lódzki Square 3, 10-718, Olsztyn, Poland. *Corresponding author (arkadiusz.stepien@uwm.edu.pl).

${ }^{2}$ University of Warmia and Mazury in Olsztyn, Faculty of Technical Sciences, Heweliusza Street 10, 10-718 Olsztyn, Poland.

${ }^{3}$ University of Warmia and Mazury in Olsztyn, Faculty of Food Sciences, Cieszyński Square 1, 10-718 Olsztyn, Poland.

${ }^{4}$ University of Warmia and Mazury in Olsztyn, Faculty of Economics, M. Oczapowskiego Street 4, 10-718 Olsztyn, Poland.

Received: 1 February 2019; Accepted: 3 July 2019; doi:10.4067/S0718-58392019000400616

\begin{abstract}
Nitrogen fertilization combined with microelements is an effective way to provide nutrients to plants, which are essential for obtaining high-value crops. The aim of this study was to evaluate two $\mathrm{N}$ fertilizer rates $\left(150\right.$ and $\left.200 \mathrm{~kg} \mathrm{ha}^{-1}\right)$ and four Mn fertilizer rates $\left(0.0,0.5,1.0\right.$, and $\left.1.5 \mathrm{~kg} \mathrm{Mn} \mathrm{ha}^{-1}\right)$ on the $\mathrm{N}, \mathrm{Mn}, \mathrm{Zn}, \mathrm{Cu}$, and $\mathrm{Fe}$ content and composition of fatty acids in winter wheat (Triticum aestivum L.) grain. An increase in the $\mathrm{N}$ fertilizer rate increased (12.7\%) the $\mathrm{Mn}$ content and decreased (10\%) the $\mathrm{Cu}$ content of wheat grain. Regardless of $\mathrm{N}$ fertilization, foliar application of $\mathrm{Mn}$ at $1.5 \mathrm{~kg} \mathrm{ha}^{-1}$ contributed to the highest $\mathrm{Zn}\left(28.4 \mathrm{mg} \mathrm{kg}^{-1}\right)$ and $\mathrm{Fe}\left(58.4 \mathrm{mg} \mathrm{kg}^{-1}\right)$ content in the grain. In an analysis of lipid fractions, the highest value of the coefficient of variation was recorded for C18:0 (16.3\%-low variation). Nitrogen and Mn fertilization were most strongly correlated with the Mn content of grain $(r=0.356, r=0.391$, respectively). The $200 \mathrm{~kg} \mathrm{~N}$ $\mathrm{ha}^{-1}$ treatments combined with $1.0 \mathrm{~kg} \mathrm{ha}^{-1} \mathrm{Mn}$ and $150 \mathrm{~kg} \mathrm{ha}^{-1} \mathrm{~N}$ without Mn were correlated with the content of C:18:0, C18:1c11, C18:1c9, and monounsaturated fatty acids in the grain. The application of $200 \mathrm{~kg} \mathrm{ha}^{-1} \mathrm{~N}$ with $1.5 \mathrm{~kg} \mathrm{ha}^{-1} \mathrm{Mn}$ was correlated with the $\mathrm{Fe}, \mathrm{Zn}$, and $\mathrm{Mn}$ content of the grain. The remaining fertilization treatments were correlated with the content of $\mathrm{C} 18: 3, \mathrm{C} 18: 2$, polyunsaturated fatty acids (PUFA), and the $\mathrm{C} 18: 2 / \mathrm{C} 18: 3$ ratio in the grain. Results indicated that the application of $200 \mathrm{~kg} \mathrm{ha}^{-1} \mathrm{~N}$ beneficially affected the PUFA content in the winter wheat grain and can therefore be used to obtain raw material with increased nutritional value. The human organism does not synthesize PUFA, so they must be taken with food (or supplements); winter wheat grain can be a good source because it contains more than 60\% PUFA.
\end{abstract}

Key words: Biofortification, lipids, nitrogen content, nutritional value of grain, Triticum aestivum.

\section{INTRODUCTION}

The biofortification with nutrients of first-class winter wheat (Triticum aestivum L.) grain, which requires the selection of the optimal farming location and the most effective agronomic practices, is more complex than improving grain quality (Jaskulska et al., 2018). The micronutrients that are essential for healthy plant growth include $\mathrm{Cu}, \mathrm{Fe}, \mathrm{Mo}, \mathrm{Zn}$, and $\mathrm{Mn}$ (Lambers et al., 2015). Root uptake contributes up to 86\% micronutrient accumulation in the grain (Liñero et al., 2018). The roles of vegetative tissues and specialized mechanisms responsible for micronutrient translocation to the grain have been extensively studied (Waters et al., 2009; Stepien and Wojtkowiak, 2016). Manganese is accumulated in plant cells where intense chemical reactions take place during the active growth stage (Fernando et al., 2012). Vegetative organs can be directly supplied with micronutrients through foliar fertilization alone or combined with macronutrients, mostly N. Foliar nutrition is very important because foliar nutrients penetrate the stomata or leaf cuticles and are easily absorbed 
by cells (Rajasekar et al., 2017). Manganese serves as a cofactor or a prosthetic group (metalloproteins) and activates enzymes responsible for breaking down carbohydrates and reducing nitrate. Manganese participates in photosynthesis, chloroplast formation, maintenance of the hormonal balance, lipid biosynthesis, and plant resistance to biotic and abiotic stresses (Socha and Guerinot, 2014). Wheat is an important source of energy, protein, and micronutrients, so that most research studies aim to improve these parameters (Zeidan et al., 2010; Wojtkowiak et al., 2018). However, the influence of agronomic factors on the fatty acid content and composition in cereal grain is less frequently investigated. Cereals are a major component of the human diet, which play important biological roles in the human body and deliver health-promoting effects due to the unique composition of fatty acids. Polyunsaturated fatty acids (PUFA), mainly linoleic acid C18:2 n-6 (LA) and linolenic acid C18:3 n-3 (ALA), produce long-chain derivatives: arachidonic acid (n-6), eicosapentaenoic acid n-3 (EPA), and docosahexaenoic acid n-3 (DHA) (Levant et al., 2010). The presence of $\mathrm{N}$ in the nutrient growth solution can promote root uptake, translocation of other nutrients (Kutman et al., 2011), and mineral homeostasis. Nitrogen contributes to effective nutrient transport, trafficking, and sequestration. This mechanism supplies trace amounts of nutrients to all cell types at all development stages, which is essential for grain biofortification (Pataco et al., 2017).

The aim of this study was to evaluate the effect of two rates of $\mathrm{N}$ fertilizer and four rates of $\mathrm{Mn}$ fertilizer on the content of $\mathrm{N}, \mathrm{Mn}, \mathrm{Zn}, \mathrm{Cu}$, and $\mathrm{Fe}$, as well as the composition of fatty acids in winter wheat grain.

\section{MATERIALS AND METHODS}

From 2013 to 2016, a two-factorial field experiment with a randomized block design and three replicates was conducted at

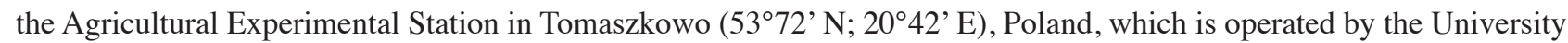
of Warmia and Mazury in Olsztyn. The experiment was established on slightly acidic ( $\mathrm{KCl}$ solution with pH 5.7) graybrown podzolic soil (classified as Haplic Cambisol according to the World Reference Base for Soil Resources, WRB 2014) with a medium silty loam granulometric composition, $10.1 \mathrm{~g} \mathrm{~kg}^{-1} \mathrm{C}$ content, moderate content of available $\mathrm{K}$ (145 $\left.\mathrm{mg} \mathrm{kg}{ }^{-1}\right), \mathrm{Mg}\left(68.7 \mathrm{mg} \mathrm{kg}^{-1}\right)$, and $\mathrm{Mn}\left(150 \mathrm{mg} \mathrm{kg}^{-1}\right)$, and high P content $\left(83.3 \mathrm{mg} \mathrm{kg}^{-1}\right)$. Plot size at harvest was $8.0 \mathrm{~m}^{2}$.

The first experimental factor included two rates of $\mathrm{N}$ fertilizer $\left(150\right.$ and $\left.200 \mathrm{~kg} \mathrm{ha}^{-1}\right)$. Nitrogen fertilizer rates and fertilization term application in phenological stages are shown in Table 1. The second experimental factor included four rates of Mn fertilizer $\left(0.0,0.5,1.0\right.$, and $\left.1.5 \mathrm{~kg} \mathrm{Mn} \mathrm{ha}^{-1}\right)$. Foliar application of Mn occurred at the stem elongation stage (BBCH 30-31) as $0.5 \%$ aqueous $\mathrm{MnSO}_{4} \cdot 5 \mathrm{H}_{2} \mathrm{O}$ solution. Mineral fertilization was supplemented with a pre-sowing application of $70 \mathrm{~kg} \mathrm{ha}^{-1} \mathrm{P}$ (triple superphosphate, 20\% P) and $100 \mathrm{~kg} \mathrm{~K} \mathrm{ha}^{-1}$ (potash salt, $46 \% \mathrm{~K}$ ).

The experimental crop was winter bread wheat (Triticum aestivum L.) 'Sailor', which is characterized by high yields, resistance to lodging, and high-quality grain with a high protein and gluten content. Wheat was sown with $12 \mathrm{~cm}$ interrow spacing after winter triticale ( $\times$ Triticosecale spp.) at 550 kernels $\mathrm{m}^{-2}$. Wheat was sown, cultivated, and harvested in accordance with the standard agronomic requirements for this species.

Samples of ground wheat grain were mineralized in $\mathrm{H}_{2} \mathrm{SO}_{4}$ in addition to $\mathrm{H}_{2} \mathrm{O}_{2}$ as an oxidizing agent. Nitrogen was determined by the Kjeldahl method in a distillation unit (KjelFlex K-360; Büchi Labortechnik AG, Flawil, Switzerland). The micronutrient content of grain mineralized in a mixture of $\mathrm{HNO}_{3}$ and $\mathrm{HClO}_{4}(4: 1)$ was determined by flame atomic absorption spectroscopy (iCE 3000 spectrometer; Thermo-Scientific, Hemel Hempstead, Hertfordshire, UK).

Oil from dried and ground wheat grain was cold pressed $(20 \mathrm{~g})$ with dichloromethane/methanol $(2: 1 \mathrm{v} / \mathrm{v})($ CequierSánchez et al., 2008). The extracted oil was esterified to determine its fatty acid composition according to the UNE-EN ISO 12966-1:2015 guideline (UNE, 2015). Lipid samples (100 mg) were combined with $2 \mathrm{M} \mathrm{NaOH}(4 \mathrm{~mL})$ and heated for $10 \mathrm{~min}$. The BF3 complex $(4 \mathrm{~mL})$ and isooctane $(3 \mathrm{~mL})$ were then added to the boiling mixture and heated for $1 \mathrm{~min}$. Immediately after removing the flask from the heat source, $20 \mathrm{~mL} 1 \% \mathrm{NaCl}$ solution was added. Afterward, $2 \mathrm{~mL}$ of the upper isooctane layer was transferred to a vial and analyzed.

Table 1. Nitrogen fertilization (type and rates of $\mathbf{N}$ fertilization and application at phenological stages).

\begin{tabular}{lcccc}
\hline & $\begin{array}{c}\text { Pre- } \\
\text { sowing }\end{array}$ & $\begin{array}{c}\text { Tillering } \\
(\mathrm{BBCH} 25-29)\end{array}$ & $\begin{array}{c}\text { Stem elongation } \\
(\mathrm{BBCH} 30-31)\end{array}$ & $\begin{array}{c}\text { Heading } \\
\text { (BBCH 51-52) }\end{array}$ \\
\cline { 2 - 5 } $\begin{array}{l}\text { Fertilizer rate } \\
\left(\mathrm{kg} \mathrm{ha}^{-1}\right)\end{array}$ & $\begin{array}{c}\text { Urea } \\
46 \%\end{array}$ & $\begin{array}{c}\text { Ammonium } \\
\text { nitrate 34\% }\end{array}$ & $\begin{array}{c}\text { Ammonium } \\
\text { nitrate 34\% }\end{array}$ & $\begin{array}{c}\text { Urea 46\% foliar application } \\
\text { with 10\% solution }\end{array}$ \\
\hline 150 & 40 & 70 & 30 & 10 \\
200 & 40 & 80 & 60 & 20 \\
\hline
\end{tabular}


Chromatographic separation was performed with a gas chromatograph (7890A, Agilent Technologies, Wilmington, Delaware, USA) with a flame-ionization detector (FID) and a capillary column $(30 \mathrm{~m} \times 0.32 \mathrm{~mm})$ (Supelco, Bellefonte, Pennsylvania, USA). The liquid phase was Supelcowax 10 and film thickness was $0.25 \mu \mathrm{m}$. The separation settings were carrier gas helium (flow rate $1 \mathrm{~mL} \mathrm{~min}^{-1}$ ), detector, and injector and column temperatures were 250,230 , and $195^{\circ} \mathrm{C}$, respectively. Fatty acids were identified by comparing retention time with known standards (Supelco).

During the 3-yr experiment, weather conditions varied considerably across growing seasons and during winter dormancy (Table 2). Spring and summer precipitation levels, which have a decisive influence on grain yield and grain quality, differed considerably across years. Total precipitation between April and July ranged from 146.8 to $285.4 \mathrm{~mm}$ during the experiment and with a long-term mean of $246.4 \mathrm{~mm}$. In April 2014 and April 2016, total monthly precipitation was below the long-term mean. Water deficit was also observed in May and June in both 2014 and 2015. In all the years of the study, precipitation levels varied the most in July. The mean monthly temperature during the most intense wheat growth (April to August) ranged from $12.9{ }^{\circ} \mathrm{C}$ in 2015 to $14.1{ }^{\circ} \mathrm{C}$ in 2016 and $14.2^{\circ} \mathrm{C}$ in 2014 , and the long-term mean was $14.0^{\circ} \mathrm{C}$.

The results were statistically processed with Statistica 13.0 (StatSoft, Tulsa, Oklahoma, USA) using two-way ANOVA. Basic parameters and homogenous groups were determined by Tukey's test at $\mathrm{p}=0.05$. Principal component analysis (PCA) was performed.

\section{RESULTS AND DISCUSSION}

The coefficients of variation relating to the content of essential micronutrients and the fatty acid composition of winter wheat grain revealed moderate variations in $\mathrm{Zn} \mathrm{(34.2 \% )}$ and $\mathrm{Cu}(25.2 \%)$ content. In an analysis of lipid fractions, the highest value of the coefficient of variation was recorded for C18:0 (16.3\%-low variation) (Table 3). During the 3-yr study, the micronutrient content of winter wheat grain was determined in the following ranges: $1.40-2.83 \mathrm{mg} \mathrm{kg}^{-1} \mathrm{Cu}$, 42.8-72.1 $\mathrm{mg} \mathrm{kg}^{-1} \mathrm{Fe}, 14.9-40.4 \mathrm{mg} \mathrm{kg}^{-1} \mathrm{Zn}$, and $20.6-38.5 \mathrm{mg} \mathrm{kg}^{-1} \mathrm{Mn}$ (Table 4).

According to Smith et al. (2018), increased yield in response to mineral fertilization is accompanied by decreased $\mathrm{Mn}$ and $\mathrm{Zn}$ content in wheat grain. In a study by Jarecki et al. (2017), fertilization decreased $\mathrm{Fe}$ and increased $\mathrm{Cu}$ and $\mathrm{Mn}$ concentrations in the grain. High rates of $\mathrm{N}$ fertilizer can potentially promote the translocation of $\mathrm{Fe}$ and $\mathrm{Zn}$ in plants (Persson et al., 2009). In the work by Shi et al. (2010), $\mathrm{N}$ fertilization increased $\mathrm{Cu}, \mathrm{Fe}$, and $\mathrm{Zn}$ concentrations in winter wheat grain compared with an unfertilized control, but an increase in the $\mathrm{N}$ rate from 130 to $300 \mathrm{~kg} \mathrm{ha}^{-1}$ did not induce further content changes in the above nutrients. The interactions between the minerals absorbed by plants are driven by ion antagonism and synergy (Sathiyavani et al., 2017). In our previous study (Stepien and Wojtkowiak, 2019), an increase in the $\mathrm{N}$ rate (from 150 to $200 \mathrm{~kg} \mathrm{ha}^{-1}$ ) had no effect on grain yield of the analyzed wheat cultivar. The above findings indicate that the grain micronutrient content should not be associated with grain yield. Many processes are responsible for micronutrient accumulation in cereal grains, including soil intake, root translocation, vegetative tissue remobilization to grains, each of which is controlled by many genes (Waters et al., 2009). In the present study, the higher $\mathrm{N}$ rate $\left(200 \mathrm{~kg} \mathrm{ha}^{-1}\right)$ applied with or without $\mathrm{Mn}$ foliar spray decreased wheat grain $\mathrm{Cu}$ content by $10 \%$ on average during the 3 -yr experiment. Regardless of $\mathrm{N}$ fertilization, foliar application of $\mathrm{Mn}$ at $1.5 \mathrm{~kg} \mathrm{ha}^{-1}$ decreased grain $\mathrm{Cu}$ content compared with the remaining fertilization treatments (not all differences were significant). An analysis of the interaction between $\mathrm{N}$ fertilization and $\mathrm{Mn}$ application

Table 2. Weather conditions for 2013-2016 and the multi-annual mean for 1981-2010.

\begin{tabular}{|c|c|c|c|c|c|c|c|c|c|c|c|c|c|}
\hline Year & Sept & Oct & Nov & Dec & Jan & Feb & Mar & Apr & May & Jun & Jul & Aug & $\begin{array}{c}\text { Sep-Aug } \\
\text { mean }\end{array}$ \\
\hline \multicolumn{14}{|c|}{ Temperature, ${ }^{\circ} \mathrm{C}$} \\
\hline 2013-2014 & 11.3 & 8.9 & 5.0 & 2.3 & -4.0 & 1.2 & 5.1 & 8.8 & 13.0 & 14.4 & 20.4 & 17.1 & 8.6 \\
\hline 2014-2015 & 13.6 & 8.7 & 3.7 & -0.4 & 0.4 & 0.5 & 4.2 & 6.7 & 11.8 & 15.5 & 17.5 & 19.8 & 8.5 \\
\hline 2015-2016 & 13.5 & 6.1 & 4.8 & 3.4 & -4.0 & 2.3 & 3.0 & 7.4 & 13.7 & 17.1 & 18.1 & 17.1 & 8.5 \\
\hline \multirow[t]{2}{*}{$1981-2010$} & 12.8 & 8.0 & 2.9 & -0.9 & -2.4 & -1.7 & 1.8 & 7.7 & 13.5 & 16.1 & 18.7 & 17.9 & 7.9 \\
\hline & \multicolumn{12}{|c|}{ Rainfall, mm } & $\begin{array}{c}\text { Sep-Aug } \\
\text { total }\end{array}$ \\
\hline 2013-2014 & 101.1 & 16.0 & 18.0 & 27.7 & 48.4 & 8.1 & 57.7 & 26.0 & 32.7 & 50.8 & 37.3 & 86.1 & 509.9 \\
\hline 2014-2015 & 25.9 & 15.1 & 34.0 & 61.8 & 46.8 & 6.8 & 45.1 & 38.2 & 29.7 & 29.5 & 81.9 & 14.3 & 429.1 \\
\hline 2015-2016 & 63.8 & 19.4 & 84.5 & 56.6 & 24.7 & 57.1 & 21.6 & 28.8 & 56.9 & 69.3 & 130.4 & 70.4 & 683.5 \\
\hline 1981-2010 & 56.9 & 42.6 & 44.8 & 38.2 & 36.4 & 24.2 & 32.9 & 33.3 & 58.5 & 80.4 & 74.2 & 59.4 & 581.7 \\
\hline
\end{tabular}


Table 3. Basic statistical measures of the micronutrient and fatty acid content of wheat grain.

\begin{tabular}{lccc}
\hline Variables & Mean $^{1}$ & Standard deviation & Coefficient of variation (\%) \\
\hline $\mathrm{Cu}$ & 2.14 & 0.541 & 25.2 \\
$\mathrm{Fe}$ & 51.7 & 7.47 & 14.5 \\
$\mathrm{Zn}$ & 22.7 & 7.765 & 34.2 \\
$\mathrm{Mn}$ & 28.4 & 4.79 & 16.9 \\
$\mathrm{C} 16: 0$ & 23.0 & 0.574 & 2.50 \\
$\mathrm{C} 18: 0$ & 0.911 & 0.149 & 16.3 \\
$\mathrm{C} 18: 1 \mathrm{c} 9$ & 11.3 & 0.656 & 5.81 \\
$\mathrm{C} 18: 1 \mathrm{c} 11$ & 0.946 & 0.064 & 6.80 \\
$\mathrm{C} 18: 2$ & 57.7 & 0.941 & 1.63 \\
$\mathrm{C} 18: 3$ & 4.29 & 0.082 & 1.90 \\
SFA & 24.8 & 0.609 & 2.46 \\
MUFA & 13.1 & 0.741 & 5.66 \\
PUFA & 62.1 & 0.990 & 1.59 \\
C18:2/C $18: 3$ & 13.5 & 0.246 & 1.83 \\
\hline
\end{tabular}

${ }^{1}$ Micronutrient ( $\left.\mathrm{mg} \mathrm{kg}^{-1}\right)$ and fatty acid (\%) content; SFA: saturated fatty acids; MUFA: monounsaturated fatty acids; PUFA: polyunsaturated fatty acids.

revealed that $\mathrm{N}$ applied at $200 \mathrm{~kg} \mathrm{ha}^{-1}$ combined with foliar application of Mn at $1.5 \mathrm{~kg} \mathrm{ha}^{-1}$ decreased $\mathrm{Cu}$ grain content in all the years of the study (32.4\% on average). Diaz et al. (2008) suggested that when $\mathrm{Cu}$ is insufficient, the retention of this component by the ripening plant causes limited $\mathrm{Cu}$ retranslocation from the vegetative parts to the grain.

The grain Fe content decreased (4.2\% on average) in the first $2 \mathrm{yr}$ and increased $(10.9 \%)$ in the third year of the experiment in response to the higher $\mathrm{N}$ fertilizer rate. Regardless of the $\mathrm{N}$ rate, the application of $1.5 \mathrm{~kg} \mathrm{ha}^{-1} \mathrm{Mn}$ led to the highest increase in grain Fe content in 2014 and 2015. In the third year of the study, the application of $1.5 \mathrm{~kg} \mathrm{ha}^{-1} \mathrm{Mn}$ increased grain $\mathrm{Fe}$ concentration, but the increase was significant only compared with the treatment without Mn foliar spraying. An increase in the $\mathrm{N}$ rate from 150 to $200 \mathrm{~kg} \mathrm{ha}^{-1}$ in the control treatment and in the $1.0 \mathrm{~kg} \mathrm{ha}^{-1} \mathrm{Mn}_{\text {treatment }}$ increased $\mathrm{Fe}$ accumulation in the wheat grain, but not all differences were significant. Grain Fe content also increased when the $200 \mathrm{~kg} \mathrm{ha}^{-1} \mathrm{~N}$ rate was combined with $0.5 \mathrm{~kg} \mathrm{ha}^{-1} \mathrm{Mn}$ in 2016 and with $1.0 \mathrm{~kg} \mathrm{ha}^{-1} \mathrm{Mn}$ in 2015 and 2016. In a study conducted under similar conditions by Stepien and Wojtkowiak (2016), the foliar application of Mn at $0.5 \mathrm{~kg} \mathrm{ha}^{-1}$ increased the Fe content of winter wheat grain.

The $200 \mathrm{~kg} \mathrm{ha}^{-1} \mathrm{~N}$ rate decreased wheat grain $\mathrm{Zn}$ content in 2015 (11.1\% on average) and increased wheat grain $\mathrm{Zn}$ content in 2016 (18.7\% on average) compared with the $150 \mathrm{~kg} \mathrm{ha}^{-1} \mathrm{~N}$ rate. According to Erenoglu et al. (2011), a higher $\mathrm{N}$ rate not only significantly increases $\mathrm{Zn}$ uptake and its translocation to vegetative organs, but also contributes to the movement of $\mathrm{Zn}$ from the flag leaf to the grain. In all the years of the study, wheat grain $\mathrm{Zn}$ content was the highest in treatments in which there was foliar application of $\mathrm{Mn}$ at $1.5 \mathrm{~kg} \mathrm{ha}^{-1}$, regardless of $\mathrm{N}$ fertilization. An analysis of the interaction between $\mathrm{N}$ and $\mathrm{Mg}$ fertilization revealed that the highest accumulation of $\mathrm{Zn}$ in the grain occurred when foliar application of Mn at $1.5 \mathrm{~kg} \mathrm{ha}^{-1}$ was combined with 150 or $200 \mathrm{~kg} \mathrm{ha}^{-1} \mathrm{~N}$ in 2014, with $150 \mathrm{~kg} \mathrm{ha}^{-1} \mathrm{~N}$ in 2015 and $200 \mathrm{~kg} \mathrm{ha}^{-1} \mathrm{~N}$ in 2016.

An increase in the $\mathrm{N}$ rate from 150 to $200 \mathrm{~kg} \mathrm{ha}^{-1}$ increased the $\mathrm{Mn}$ content of wheat grain in all the years of the study (12.7\% on average). Not all treatments with foliar application of $\mathrm{Mn}$ responded alike to an increase in the $\mathrm{N}$ rate. Nitrogen fertilization induced a clear increase in the Mn grain content only in the control treatment in 2014, control treatment and $0.5 \mathrm{~kg} \mathrm{ha}^{-1} \mathrm{Mn}$ treatment in 2015, and in all Mn treatments in 2016.

In a study by Pahlavan-Rad and Pessarakli (2009), the foliar application of $0.5 \% \mathrm{MnSO}_{4}$ solution increased the $\mathrm{Mn}$ concentration in the wheat grain, but did not affect the Fe and $\mathrm{Zn}$ grain content. In the work by Narwal et al. (2012), the highest accumulation of Fe and $\mathrm{Mn}$ in the grain was reported when Fe and $\mathrm{Mn}$ sulfate salts were applied as $0.5 \%$ foliar solution. These results indicate that $\mathrm{Fe}$ and $\mathrm{Mn}$ are more effectively absorbed by wheat leaves, as confirmed by their translocation from leaves to grain. An increase in the $\mathrm{Cu}$ and $\mathrm{Fe}$ grain content under the influence of Mn fertilization was also reported by Zeidan et al. (2010) and Stepien and Wojtkowiak (2016). Micronutrient concentrations in plant tissues are influenced by the mode of fertilizer application (to soil or leaves). The effectiveness of nutrient transport to the grain is also determined by phloem mobility (Fernández and Brown, 2013). Increasing or decreasing micronutrient content in plants can result from antagonistic or synergistic interactions between the forms of $\mathrm{N}$ supplied in fertilizers and microelements at the plant uptake stage (Diatta and Grzebisz, 2006). Page and Feller (2015) observed low remobilization 
Table 4. Micronutrient content (Cu, Fe, $\mathrm{Zn}, \mathrm{Mn})$ of wheat grain under different integrated treatments from 2014 to 2016.

\begin{tabular}{|c|c|c|c|c|c|c|}
\hline \multirow[b]{2}{*}{ Year } & \multirow[b]{2}{*}{$\mathrm{N}$ rate } & \multicolumn{4}{|c|}{ Mn rate $\left(\mathrm{kg} \mathrm{ha}^{-1}\right)$} & \multirow[b]{2}{*}{ Mean } \\
\hline & & 0.0 & 0.5 & 1.0 & 1.5 & \\
\hline & $\mathrm{kg} \mathrm{ha}^{-1}$ & 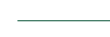 & $-\mathrm{Cl}$ & $\left.\mathrm{g}^{-1}\right)$ & $\bar{\tau}$ & \\
\hline \multirow[t]{3}{*}{2014} & 150 & $2.54 \mathrm{a}$ & $2.65 \mathrm{a}$ & $2.55 \mathrm{a}$ & $2.65 \mathrm{a}$ & $2.60 \mathrm{a}$ \\
\hline & 200 & $2.45 \mathrm{a}$ & $2.57 \mathrm{a}$ & $2.68 \mathrm{a}$ & $1.67 \mathrm{~b}$ & $2.34 \mathrm{~b}$ \\
\hline & Mean & $2.50 \mathrm{a}$ & $2.61 \mathrm{a}$ & $2.61 \mathrm{a}$ & $2.16 \mathrm{~b}$ & - \\
\hline \multirow[t]{3}{*}{2015} & 150 & $2.54 \mathrm{a}$ & $2.57 \mathrm{a}$ & $2.43 \mathrm{a}$ & $2.63 \mathrm{a}$ & $2.54 \mathrm{a}$ \\
\hline & 200 & $2.25 \mathrm{ab}$ & $2.37 \mathrm{ab}$ & $2.83 \mathrm{a}$ & $1.80 \mathrm{~b}$ & $2.31 \mathrm{~b}$ \\
\hline & Mean & $2.40 \mathrm{ab}$ & $2.47 \mathrm{ab}$ & $2.63 \mathrm{a}$ & $2.22 b$ & - \\
\hline \multirow[t]{4}{*}{2016} & 150 & $1.60 \mathrm{~b}$ & $1.43 \mathrm{~b}$ & $1.43 \mathrm{~b}$ & $2.00 \mathrm{a}$ & $1.62 \mathrm{a}$ \\
\hline & 200 & $1.53 b$ & $1.40 \mathrm{~b}$ & $1.40 \mathrm{~b}$ & $1.43 \mathrm{~b}$ & $1.44 \mathrm{~b}$ \\
\hline & Mean & $1.57 \mathrm{a}$ & $1.42 \mathrm{a}$ & $1.42 \mathrm{a}$ & $1.72 \mathrm{a}$ & - \\
\hline & & & $\mathrm{F}$ & $\left.\mathrm{g}^{-1}\right)$ & & \\
\hline \multirow[t]{3}{*}{2014} & 150 & $45.6 b$ & $47.3 \mathrm{a}$ & $46.0 \mathrm{~b}$ & $64.8 \mathrm{a}$ & $50.9 \mathrm{a}$ \\
\hline & 200 & $46.8 \mathrm{a}$ & $45.3 \mathrm{~b}$ & $49.6 \mathrm{~b}$ & $57.8 \mathrm{a}$ & $49.9 b$ \\
\hline & Mean & $46.2 b$ & $46.3 b$ & $47.8 \mathrm{~b}$ & $61.3 \mathrm{a}$ & - \\
\hline \multirow[t]{3}{*}{2015} & 150 & $44.3 \mathrm{~d}$ & $45.8 \mathrm{~d}$ & $45.5 \mathrm{~d}$ & $72.1 \mathrm{a}$ & $51.9 \mathrm{a}$ \\
\hline & 200 & $56.4 \mathrm{~b}$ & $45.8 \mathrm{~d}$ & $49.4 \mathrm{c}$ & $42.8 \mathrm{~d}$ & $48.6 b$ \\
\hline & Mean & $50.3 b$ & $45.8 \mathrm{c}$ & $47.5 \mathrm{c}$ & $57.5 \mathrm{a}$ & - \\
\hline \multirow[t]{4}{*}{2016} & 150 & 49.8ef & 53.6de & $47.0 \mathrm{f}$ & $56.0 \mathrm{bcd}$ & $51.6 \mathrm{~b}$ \\
\hline & 200 & $52.0 \mathrm{de}$ & $58.1 \mathrm{ab}$ & $62.0 \mathrm{a}$ & $56.8 \mathrm{bc}$ & $57.2 \mathrm{a}$ \\
\hline & Mean & $50.9 b$ & $55.8 \mathrm{a}$ & $54.5 \mathrm{a}$ & $56.4 \mathrm{a}$ & - \\
\hline & & & $-\mathrm{Zr}$ & & & \\
\hline \multirow[t]{3}{*}{2014} & 150 & $15.4 \mathrm{c}$ & $14.9 \mathrm{c}$ & $19.6 \mathrm{~b}$ & $29.1 \mathrm{a}$ & $19.8 \mathrm{a}$ \\
\hline & 200 & $15.3 \mathrm{c}$ & $16.3 \mathrm{bc}$ & $17.4 \mathrm{bc}$ & $27.0 \mathrm{a}$ & $19.0 \mathrm{a}$ \\
\hline & Mean & $15.4 \mathrm{c}$ & $15.6 \mathrm{c}$ & $18.5 b$ & $28.1 \mathrm{a}$ & - \\
\hline \multirow[t]{3}{*}{2015} & 150 & $14.9 \mathrm{c}$ & $15.4 \mathrm{c}$ & $18.4 \mathrm{~b}$ & $26.8 \mathrm{a}$ & $18.9 \mathrm{a}$ \\
\hline & 200 & $19.3 b$ & $16.0 \mathrm{c}$ & $15.6 \mathrm{c}$ & $16.4 \mathrm{c}$ & $16.8 \mathrm{~b}$ \\
\hline & Mean & $17.1 \mathrm{~b}$ & $15.7 \mathrm{c}$ & $17.0 \mathrm{~b}$ & $21.6 \mathrm{a}$ & - \\
\hline \multirow[t]{4}{*}{2016} & 150 & $26.8 \mathrm{a}$ & $28.8 \mathrm{a}$ & $27.0 \mathrm{a}$ & $30.6 a$ & $28.3 b$ \\
\hline & 200 & $28.6 a$ & $32.4 \mathrm{a}$ & $32.4 \mathrm{a}$ & $40.4 \mathrm{a}$ & $33.6 \mathrm{a}$ \\
\hline & Mean & $27.7 \mathrm{c}$ & $30.9 \mathrm{ab}$ & $29.7 \mathrm{ab}$ & $35.5 \mathrm{a}$ & - \\
\hline & & & $\mathrm{M}$ & $\left(g^{-1}\right)$ & & \\
\hline \multirow[t]{3}{*}{2014} & 150 & $20.6 \mathrm{~d}$ & $23.6 \mathrm{~cd}$ & $26.0 \mathrm{bc}$ & $29.5 \mathrm{ab}$ & $24.9 \mathrm{~b}$ \\
\hline & 200 & $26.2 b c$ & $26.9 b c$ & $29.5 \mathrm{ab}$ & $33.8 \mathrm{a}$ & $29.1 \mathrm{a}$ \\
\hline & Mean & $23.4 \mathrm{c}$ & $25.3 \mathrm{bc}$ & $27.8 \mathrm{~b}$ & $31.6 \mathrm{a}$ & - \\
\hline \multirow[t]{3}{*}{2015} & 150 & 22.6de & $21.8 \mathrm{e}$ & $25.6 a b c$ & $25.8 \mathrm{abc}$ & $24.0 \mathrm{~b}$ \\
\hline & 200 & $27.5 \mathrm{a}$ & $24.8 \mathrm{bc}$ & $27.0 \mathrm{ab}$ & $24.4 \mathrm{~cd}$ & $26.0 \mathrm{a}$ \\
\hline & Mean & $25.1 \mathrm{a}$ & $23.3 b$ & $26.3 \mathrm{a}$ & $25.1 \mathrm{a}$ & - \\
\hline \multirow[t]{3}{*}{2016} & 150 & $30.2 \mathrm{~d}$ & $29.0 \mathrm{~d}$ & $31.0 \mathrm{~cd}$ & $34.4 \mathrm{bc}$ & $31.2 \mathrm{~b}$ \\
\hline & 200 & $30.8 \mathrm{~cd}$ & $35.0 \mathrm{ab}$ & $36.4 \mathrm{ab}$ & $38.5 \mathrm{a}$ & $35.2 \mathrm{a}$ \\
\hline & Mean & $30.5 \mathrm{c}$ & $32.0 \mathrm{bc}$ & $33.7 \mathrm{~b}$ & $36.5 \mathrm{a}$ & - \\
\hline
\end{tabular}

Means in two rows (same year) followed by the same letter are nonsignificant $(\alpha<0.05)$.

of Fe and Mn from leaves to grain. In a study by Curtin et al. (2008), foliar application of Mn increased Mn concentration in vegetative tissues, but induced only a minor increase in Mn grain content.

According to Ciolek et al. (2012) and Escarnot et al. (2012), the lipid content of wheat grain ranges from $1 \%$ to $3 \%$. This is a very stable trait that is genetically conditioned (Konopka et al., 2017). In the present study, the lipid content of wheat grain was similar, ranging from $1.19 \%$ to $1.36 \%$. Agronomic factors ( $\mathrm{N}$ fertilization and $\mathrm{Mn}$ application) led to minor differences in the lipid content of wheat grain (data not shown).

The extracted oil from the wheat grain was characterized by a typical composition of fatty acids, with a predominance $(\sim 58 \%)$ of $\omega-6$ linoleic acid (C18:2) (Table 5); this corroborates findings by Ciolek et al. (2012) and Konopka et al. (2017). The remaining fatty acids included oleic acid $(\mathrm{C} 18: 1 \mathrm{c} 9+\mathrm{c} 11 ; \sim 12 \%), \alpha$-linolenic acid $(\mathrm{C} 18: 3, \omega-3 ;>4 \%)$, and palmitic acid (C16:0; 23\%). In a study by Wojtkowiak et al. (2018), increasing $\mathrm{N}$ fertilization levels had nonsignificant effect on the fatty acid profile of wheat grain. 
Table 5. Fatty acid profile (\%) in grain under different integrated treatments from 2014 to 2016.

\begin{tabular}{|c|c|c|c|c|c|c|}
\hline \multirow[b]{2}{*}{ Year } & \multirow[b]{2}{*}{$\mathrm{N}$ rate } & \multicolumn{4}{|c|}{ Mn rate $\left(\mathrm{kg} \mathrm{ha}^{-1}\right)$} & \multirow[b]{2}{*}{ Mean } \\
\hline & & 0.0 & 0.5 & 1.0 & 1.5 & \\
\hline & $\mathrm{kg} \mathrm{ha}^{-1}$ & & - & & - & \\
\hline \multirow[t]{3}{*}{2014} & 150 & $23.4 \mathrm{a}$ & $23.1 \mathrm{a}$ & $23.4 \mathrm{a}$ & $22.9 \mathrm{a}$ & $23.2 \mathrm{a}$ \\
\hline & 200 & $22.6 a$ & $23.6 a$ & $23.5 \mathrm{a}$ & $23.4 \mathrm{a}$ & $23.3 \mathrm{a}$ \\
\hline & Mean & $23.0 \mathrm{a}$ & $23.4 \mathrm{a}$ & $23.5 \mathrm{a}$ & $23.2 \mathrm{a}$ & - \\
\hline \multirow{3}{*}{2015} & 150 & $23.0 \mathrm{a}$ & $23.1 \mathrm{a}$ & $22.7 \mathrm{a}$ & $22.8 \mathrm{a}$ & $22.9 \mathrm{a}$ \\
\hline & 200 & $23.4 \mathrm{a}$ & $22.9 \mathrm{a}$ & $22.9 a$ & $23.0 \mathrm{a}$ & $23.1 \mathrm{a}$ \\
\hline & Mean & $23.2 \mathrm{a}$ & $23.0 \mathrm{a}$ & $22.8 \mathrm{a}$ & $22.9 \mathrm{a}$ & - \\
\hline \multirow[t]{4}{*}{2016} & 150 & $23.2 \mathrm{a}$ & $22.7 \mathrm{a}$ & $22.8 \mathrm{a}$ & $22.3 \mathrm{a}$ & $22.8 \mathrm{a}$ \\
\hline & 200 & $22.9 \mathrm{a}$ & $22.5 \mathrm{a}$ & $22.7 \mathrm{a}$ & $22.4 \mathrm{a}$ & $22.6 \mathrm{a}$ \\
\hline & Mean & $23.1 \mathrm{a}$ & $22.6 a$ & $22.8 \mathrm{a}$ & $22.4 \mathrm{a}$ & - \\
\hline & & & $\overline{ }$ & & - & \\
\hline \multirow[t]{3}{*}{2014} & 150 & $0.697 \mathrm{~g}$ & $0.736 \mathrm{ef}$ & $0.764 d$ & $0.719 \mathrm{f}$ & $0.729 b$ \\
\hline & 200 & $0.752 \mathrm{de}$ & $0.920 \mathrm{a}$ & $0.869 b$ & $0.818 \mathrm{c}$ & $0.840 \mathrm{a}$ \\
\hline & Mean & $0.724 d$ & $0.827 \mathrm{a}$ & $0.816 \mathrm{c}$ & $0.768 b$ & - \\
\hline \multirow[t]{3}{*}{2015} & 150 & $0.951 \mathrm{~cd}$ & $0.941 d$ & $0.972 b c$ & $1.013 \mathrm{a}$ & $0.969 b$ \\
\hline & 200 & $0.985 b$ & $0.976 b$ & $1.025 \mathrm{a}$ & $0.981 b$ & $0.992 \mathrm{a}$ \\
\hline & Mean & $0.968 b$ & $0.959 \mathrm{~b}$ & $0.999 \mathrm{a}$ & $0.997 \mathrm{a}$ & - \\
\hline \multirow[t]{4}{*}{2016} & 150 & $1.453 \mathrm{a}$ & $1.005 b$ & $0.889 \mathrm{c}$ & $0.891 \mathrm{c}$ & $1.059 \mathrm{a}$ \\
\hline & 200 & $0.895 \mathrm{c}$ & $0.893 \mathrm{c}$ & $0.883 c$ & $0.857 \mathrm{c}$ & $0.882 b$ \\
\hline & Mean & $1.174 \mathrm{a}$ & $0.949 b$ & $0.886 \mathrm{c}$ & $0.874 \mathrm{c}$ & - \\
\hline & & & $-\mathrm{C} 1$ & 11 & - & \\
\hline \multirow[t]{3}{*}{2014} & 150 & $11.7 \mathrm{a}$ & $11.7 \mathrm{a}$ & $11.9 \mathrm{a}$ & $12.0 \mathrm{a}$ & $11.82 \mathrm{a}$ \\
\hline & 200 & $11.9 \mathrm{a}$ & $12.0 \mathrm{a}$ & $11.9 \mathrm{a}$ & $11.6 \mathrm{a}$ & $11.86 \mathrm{a}$ \\
\hline & Mean & $11.8 \mathrm{a}$ & $11.9 \mathrm{a}$ & $11.9 \mathrm{a}$ & $11.8 \mathrm{a}$ & - \\
\hline \multirow[t]{3}{*}{2015} & 150 & $12.4 \mathrm{a}$ & $12.1 \mathrm{a}$ & $12.4 \mathrm{a}$ & $12.2 \mathrm{a}$ & $12.30 \mathrm{a}$ \\
\hline & 200 & $11.9 \mathrm{a}$ & $12.0 \mathrm{a}$ & $12.5 \mathrm{a}$ & $12.0 \mathrm{a}$ & $12.10 \mathrm{a}$ \\
\hline & Mean & $12.2 \mathrm{a}$ & $12.1 \mathrm{a}$ & $12.5 \mathrm{a}$ & $12.1 \mathrm{a}$ & - \\
\hline \multirow[t]{3}{*}{2016} & 150 & $14.4 \mathrm{a}$ & $12.6 \mathrm{~b}$ & $12.2 \mathrm{~b}$ & $12.6 b$ & $13.00 \mathrm{a}$ \\
\hline & 200 & $12.3 \mathrm{~b}$ & $12.3 \mathrm{~b}$ & $12.4 \mathrm{~b}$ & $12.5 b$ & $12.40 \mathrm{~b}$ \\
\hline & Mean & $13.4 \mathrm{a}$ & $12.5 \mathrm{ab}$ & $12.3 b$ & $12.6 \mathrm{ab}$ & - \\
\hline \multirow[t]{3}{*}{2014} & 150 & $57.8 \mathrm{a}$ & $58.3 \mathrm{a}$ & $57.7 \mathrm{a}$ & $58.0 \mathrm{a}$ & $58.00 \mathrm{a}$ \\
\hline & 200 & $58.6 \mathrm{a}$ & $57.6 \mathrm{a}$ & $57.5 \mathrm{a}$ & $58.2 \mathrm{a}$ & $57.93 \mathrm{a}$ \\
\hline & Mean & $58.2 \mathrm{a}$ & $58.0 \mathrm{a}$ & $57.6 \mathrm{a}$ & $58.1 \mathrm{a}$ & - \\
\hline \multirow[t]{3}{*}{2015} & 150 & $57.5 \mathrm{a}$ & $57.8 \mathrm{a}$ & $57.9 \mathrm{a}$ & $58.0 \mathrm{a}$ & $57.80 \mathrm{a}$ \\
\hline & 200 & $57.4 \mathrm{a}$ & $58.1 \mathrm{a}$ & $57.3 \mathrm{a}$ & $57.8 \mathrm{a}$ & $57.70 \mathrm{a}$ \\
\hline & Mean & $57.5 \mathrm{a}$ & $58.0 \mathrm{a}$ & $57.6 \mathrm{a}$ & $57.9 \mathrm{a}$ & - \\
\hline 2016 & 150 & $54.5 \mathrm{~b}$ & $57.4 \mathrm{a}$ & $57.9 \mathrm{a}$ & $57.9 a$ & $56.90 \mathrm{a}$ \\
\hline & 200 & $57.7 \mathrm{a}$ & $58.0 \mathrm{a}$ & $58.0 \mathrm{a}$ & $58.0 \mathrm{a}$ & $57.90 \mathrm{~b}$ \\
\hline & Mean & $56.1 \mathrm{~b}$ & $57.7 \mathrm{a}$ & $58.0 \mathrm{a}$ & $58.0 \mathrm{a}$ & - \\
\hline & & & $-\quad \mathrm{C} 18$ & & 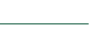 & \\
\hline 2014 & 150 & $4.66 \mathrm{a}$ & $4.33 \mathrm{a}$ & $4.32 \mathrm{a}$ & $4.29 \mathrm{a}$ & $4.33 \mathrm{a}$ \\
\hline & 200 & $4.35 \mathrm{a}$ & $4.25 \mathrm{a}$ & $4.41 \mathrm{a}$ & $4.35 \mathrm{a}$ & $4.34 \mathrm{a}$ \\
\hline & Mean & $4.36 \mathrm{a}$ & $4.29 \mathrm{a}$ & $4.37 \mathrm{a}$ & $4.32 \mathrm{a}$ & - \\
\hline 2015 & 150 & $4.29 \mathrm{ab}$ & $4.34 \mathrm{ab}$ & $4.38 \mathrm{a}$ & $4.32 \mathrm{ab}$ & $4.33 \mathrm{a}$ \\
\hline & 200 & $4.28 \mathrm{ab}$ & $4.32 \mathrm{ab}$ & $4.21 \mathrm{~b}$ & $4.28 \mathrm{ab}$ & $4.27 \mathrm{~b}$ \\
\hline & Mean & $4.29 \mathrm{a}$ & $4.33 \mathrm{a}$ & $4.30 \mathrm{a}$ & $4.30 \mathrm{a}$ & - \\
\hline 2016 & 150 & $4.16 \mathrm{a}$ & $4.14 \mathrm{a}$ & $4.27 \mathrm{a}$ & $4.29 \mathrm{a}$ & $4.22 \mathrm{a}$ \\
\hline & 200 & $4.21 \mathrm{a}$ & $4.30 \mathrm{a}$ & $4.21 \mathrm{a}$ & $4.27 \mathrm{a}$ & $4.25 \mathrm{a}$ \\
\hline & Mean & $4.19 \mathrm{a}$ & $4.22 \mathrm{a}$ & $4.24 \mathrm{a}$ & $4.28 \mathrm{a}$ & - \\
\hline & & & - Othe & tion & 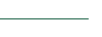 & \\
\hline 2014 & 150 & $1.66 \mathrm{a}$ & $1.55 \mathrm{ab}$ & $1.57 \mathrm{ab}$ & $1.59 \mathrm{ab}$ & $1.59 \mathrm{a}$ \\
\hline & 200 & $1.56 \mathrm{ab}$ & $1.37 \mathrm{c}$ & $1.56 \mathrm{ab}$ & $1.51 \mathrm{~b}$ & $1.50 \mathrm{~b}$ \\
\hline & Mean & $1.61 \mathrm{a}$ & $1.46 \mathrm{~b}$ & $1.56 \mathrm{a}$ & $1.55 \mathrm{a}$ & - \\
\hline 2015 & 150 & $1.57 \mathrm{~b}$ & $1.41 \mathrm{~cd}$ & $1.38 \mathrm{~d}$ & $1.35 \mathrm{~d}$ & $1.43 \mathrm{~b}$ \\
\hline & 200 & $1.59 \mathrm{~b}$ & $1.49 b c$ & $1.71 \mathrm{a}$ & $1.53 \mathrm{~b}$ & $1.58 \mathrm{a}$ \\
\hline & Mean & $1.58 \mathrm{a}$ & $1.45 \mathrm{~b}$ & $1.54 \mathrm{a}$ & $1.44 \mathrm{~b}$ & - \\
\hline 2016 & 150 & $1.79 \mathrm{a}$ & $1.64 b c$ & $1.65 b c$ & $1.71 \mathrm{ab}$ & $1.70 \mathrm{a}$ \\
\hline & 200 & $1.63 \mathrm{c}$ & $1.60 \mathrm{c}$ & $1.46 \mathrm{~d}$ & $1.63 \mathrm{c}$ & $1.58 \mathrm{~b}$ \\
\hline & Mean & $1.71 \mathrm{a}$ & $1.62 \mathrm{~b}$ & $1.56 \mathrm{c}$ & $1.67 \mathrm{a}$ & - \\
\hline
\end{tabular}

Mean in two rows (same year) followed by the same letter are nonsignificant $(\alpha<0.05)$. 
An increase in the $\mathrm{N}$ rate (from 150 to $200 \mathrm{~kg} \mathrm{ha}^{-1}$ ) increased C18:0 acid content in 2014 and 2015, and increased the total concentrations of the remaining fatty acids $(\mathrm{C} 12: 0, \mathrm{C} 14: 0, \mathrm{C} 15: 0, \mathrm{C} 16: 1, \mathrm{C} 17: 0, \mathrm{C} 17: 1, \mathrm{C} 20: 0, \mathrm{C} 20: 1, \mathrm{C} 20: 2$, and $\mathrm{C} 22: 0)$ in 2015. The higher $\mathrm{N}$ rate decreased $\mathrm{C} 18: 0, \mathrm{C} 18: 1 \mathrm{c} 9+\mathrm{c} 11$, and $\mathrm{C} 18: 2$ content as well as the total concentrations of the remaining fatty acids in 2016; it decreased the content of C18:3 n-3+n-6 in 2015 and decreased the total concentrations of the remaining fatty acids in 2014 .

The C18:2 content, which had the highest share of the total fatty acid pool, increased significantly in response to foliar application of Mn only in 2016. The foliar application of Mn and the interaction between $\mathrm{Mn}$ and $\mathrm{N}$ fertilization exerted varied effects on the content of the remaining fatty acid groups. The role of $\mathrm{Mn}$ in lipid metabolism is more complex. It increases the content of typical thylakoid membrane constituents such as glycolipids and PUFA (Salama et al., 2015). The extracted oil contained on average 62.3\% PUFA, 24.5\% saturated fatty acids (SFA), and 13.2\% monounsaturated fatty acids (MUFA) (Table 6). The C18:2 ( $\omega-6)$ to $\mathrm{C} 18: 3 \mathrm{n}-3+\mathrm{n}-6(\omega-3)$ ratio was 13.5:1. The recommended dietary ratio of n-6

Table 6. Saturated fatty acids (SFA), monounsaturated fatty acids (MUFA), polyunsaturated fatty acids (PUFA), \% content, and C18:2/C18:3 ratio in wheat grain from 2014 to 2016.

\begin{tabular}{|c|c|c|c|c|c|c|}
\hline \multirow[b]{2}{*}{ Year } & \multirow[b]{2}{*}{$\mathrm{N}$ rate } & \multicolumn{4}{|c|}{ Mn rate $\left(\mathrm{kg} \mathrm{ha}^{-1}\right)$} & \multirow[b]{2}{*}{ Mean } \\
\hline & & 0.0 & 0.5 & 1.0 & 1.5 & \\
\hline & $\mathrm{kg} \mathrm{ha}^{-1}$ & 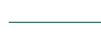 & - Sat & $\mathrm{y}$ acids & L & \\
\hline \multirow[t]{3}{*}{2014} & 150 & $24.8 \mathrm{a}$ & $24.4 \mathrm{a}$ & $24.8 \mathrm{a}$ & $24.2 \mathrm{a}$ & $24.5 \mathrm{a}$ \\
\hline & 200 & $23.9 \mathrm{a}$ & $24.9 \mathrm{a}$ & $24.9 \mathrm{a}$ & $24.8 \mathrm{a}$ & $24.6 \mathrm{a}$ \\
\hline & Mean & $24.3 \mathrm{a}$ & $24.7 \mathrm{a}$ & $24.8 \mathrm{a}$ & $24.5 \mathrm{a}$ & - \\
\hline \multirow[t]{3}{*}{2015} & 150 & $24.5 \mathrm{a}$ & $24.5 \mathrm{a}$ & $24.1 \mathrm{a}$ & $24.2 \mathrm{a}$ & $24.3 \mathrm{a}$ \\
\hline & 200 & $25.0 \mathrm{a}$ & $24.4 \mathrm{a}$ & $24.5 \mathrm{a}$ & $24.5 \mathrm{a}$ & $24.6 \mathrm{a}$ \\
\hline & Mean & $24.8 \mathrm{a}$ & $24.5 \mathrm{a}$ & $24.3 \mathrm{a}$ & $24.4 \mathrm{a}$ & - \\
\hline \multirow[t]{4}{*}{2016} & 150 & $25.3 \mathrm{a}$ & $24.3 \mathrm{a}$ & $24.3 \mathrm{a}$ & $23.8 \mathrm{a}$ & $24.4 \mathrm{a}$ \\
\hline & 200 & $24.4 \mathrm{a}$ & $24.0 \mathrm{a}$ & $24.1 \mathrm{a}$ & $23.8 \mathrm{a}$ & $24.1 \mathrm{a}$ \\
\hline & Mean & $24.8 \mathrm{a}$ & $24.1 \mathrm{ab}$ & $24.2 \mathrm{ab}$ & $23.8 \mathrm{~b}$ & - \\
\hline & & & Monoun & fatty acids & & \\
\hline \multirow[t]{3}{*}{2014} & 150 & $12.5 \mathrm{a}$ & $12.5 \mathrm{a}$ & $12.7 \mathrm{a}$ & $12.9 \mathrm{a}$ & $12.6 \mathrm{a}$ \\
\hline & 200 & $12.8 \mathrm{a}$ & $12.8 \mathrm{a}$ & $12.8 \mathrm{a}$ & $12.4 \mathrm{a}$ & $13.0 \mathrm{a}$ \\
\hline & Mean & $12.6 \mathrm{a}$ & $12.7 \mathrm{a}$ & $12.8 \mathrm{a}$ & $12.6 \mathrm{a}$ & - \\
\hline \multirow[t]{3}{*}{2015} & 150 & $13.2 \mathrm{a}$ & $12.9 \mathrm{a}$ & $13.2 \mathrm{a}$ & $12.0 \mathrm{a}$ & $13.1 \mathrm{a}$ \\
\hline & 200 & $12.7 \mathrm{a}$ & $12.8 \mathrm{a}$ & $13.5 \mathrm{a}$ & $12.8 \mathrm{a}$ & $13.0 \mathrm{a}$ \\
\hline & Mean & $13.0 \mathrm{a}$ & $12.8 \mathrm{a}$ & $13.4 \mathrm{a}$ & $12.9 \mathrm{a}$ & - \\
\hline \multirow[t]{3}{*}{2016} & 150 & $15.5 \mathrm{a}$ & $13.6 \mathrm{~b}$ & $13.1 \mathrm{~b}$ & $13.5 b$ & $13.9 \mathrm{a}$ \\
\hline & 200 & $13.2 \mathrm{~b}$ & $13.2 \mathrm{~b}$ & $13.2 \mathrm{~b}$ & $13.4 \mathrm{~b}$ & $13.3 \mathrm{~b}$ \\
\hline & Mean & $14.3 \mathrm{a}$ & $13.4 \mathrm{~b}$ & $13.2 \mathrm{~b}$ & $13.5 \mathrm{ab}$ & - \\
\hline & & & Polyun & atty acids & - & \\
\hline \multirow[t]{3}{*}{2014} & 150 & $62.4 \mathrm{a}$ & $62.8 \mathrm{a}$ & $62.1 \mathrm{a}$ & $62.7 \mathrm{a}$ & $62.5 \mathrm{a}$ \\
\hline & 200 & $62.1 \mathrm{a}$ & $62.0 \mathrm{a}$ & $62.2 \mathrm{a}$ & $62.5 \mathrm{a}$ & $62.4 \mathrm{a}$ \\
\hline & Mean & $62.7 \mathrm{a}$ & $62.4 \mathrm{a}$ & $62.1 \mathrm{a}$ & $62.6 \mathrm{a}$ & - \\
\hline \multirow[t]{3}{*}{2015} & 150 & $61.9 \mathrm{a}$ & $62.3 \mathrm{a}$ & $62.4 \mathrm{a}$ & $62.5 \mathrm{a}$ & $62.3 \mathrm{a}$ \\
\hline & 200 & $61.8 \mathrm{a}$ & $62.6 \mathrm{a}$ & $61.7 \mathrm{a}$ & $62.2 \mathrm{a}$ & $62.1 \mathrm{a}$ \\
\hline & Mean & $61.1 \mathrm{a}$ & $62.4 \mathrm{a}$ & $62.1 \mathrm{a}$ & $62.4 \mathrm{a}$ & - \\
\hline \multirow[t]{4}{*}{2016} & 150 & $58.8 \mathrm{~b}$ & $61.7 \mathrm{a}$ & $62.3 \mathrm{a}$ & $62.4 \mathrm{a}$ & $61.3 \mathrm{~b}$ \\
\hline & 200 & $62.1 \mathrm{a}$ & $62.5 \mathrm{a}$ & $62.3 \mathrm{a}$ & $62.4 \mathrm{a}$ & $62.3 \mathrm{a}$ \\
\hline & Mean & $60.4 \mathrm{~b}$ & $62.1 \mathrm{a}$ & $62.3 \mathrm{a}$ & $62.4 \mathrm{a}$ & - \\
\hline & & & - C18:2 & $3+n-6$ & - & \\
\hline \multirow{3}{*}{2014} & 150 & $13.3 \mathrm{bc}$ & $13.5 \mathrm{ab}$ & $13.4 \mathrm{ab}$ & $13.7 \mathrm{a}$ & $13.4 \mathrm{a}$ \\
\hline & 200 & $13.5 \mathrm{ab}$ & $13.6 \mathrm{ab}$ & $13.0 \mathrm{c}$ & $13.3 \mathrm{abc}$ & $13.3 \mathrm{a}$ \\
\hline & Mean & $13.4 \mathrm{ab}$ & $13.5 \mathrm{a}$ & $13.2 \mathrm{~b}$ & $13.5 \mathrm{a}$ & - \\
\hline \multirow[t]{3}{*}{2015} & 150 & $13.4 \mathrm{a}$ & $13.3 \mathrm{a}$ & $13.2 \mathrm{a}$ & $13.4 \mathrm{a}$ & $13.3 \mathrm{a}$ \\
\hline & 200 & $13.4 \mathrm{a}$ & $13.5 \mathrm{a}$ & $13.6 \mathrm{a}$ & $13.5 \mathrm{a}$ & $13.5 \mathrm{a}$ \\
\hline & Mean & $13.4 \mathrm{a}$ & $13.4 \mathrm{a}$ & $13.4 \mathrm{a}$ & $13.5 \mathrm{a}$ & - \\
\hline \multirow[t]{3}{*}{2016} & 150 & $13.1 \mathrm{~b}$ & $13.9 \mathrm{a}$ & $13.6 \mathrm{a}$ & $13.5 \mathrm{a}$ & $13.5 \mathrm{a}$ \\
\hline & 200 & $13.7 \mathrm{a}$ & $13.5 \mathrm{a}$ & $13.8 \mathrm{a}$ & $13.6 \mathrm{a}$ & $13.6 \mathrm{a}$ \\
\hline & Mean & $13.4 \mathrm{a}$ & $13.7 \mathrm{a}$ & $13.7 \mathrm{a}$ & $13.5 \mathrm{a}$ & - \\
\hline
\end{tabular}

Means in two rows (same year) followed by the same letter are nonsignificant $(\alpha<0.05)$. 
to n-3 PUFA is 4-5:1, which should not exceed 10:1 (Candela et al., 2011). Ciolek et al. (2012) confirmed that the high $\mathrm{C} 18: 2(\omega-6)$ to $\mathrm{C} 18: 3(\omega-3)$ ratio in cereal grain is genetically conditioned. The higher $\mathrm{N}$ rate in 2016 and application of $\mathrm{Mn}$ increased the proportion of PUFA and decreased the proportion of MUFA in wheat grain. The interaction between $\mathrm{N}$ and $\mathrm{Mn}$ fertilization only slightly modified fatty acid composition and the C18:2 to C18:3 n-3 + n-6 ratio in wheat grain; the observed differences were nonsignificant.

In the group of the evaluated experimental factors and variables, $\mathrm{N}$ and $\mathrm{Mn}$ fertilization were most strongly correlated with the Mn content of wheat grain (Table 7). The foliar application of Mn was also correlated with the Fe, Zn, C18:2, and PUFA concentrations in the grain. There was a negative correlation between Mn fertilization and the SFA grain content.

The correlations between the input variables and the principal components are graphically illustrated in Figure 1. Two groups of variables formed direction vectors. The first group consisted of C18:1c9, C18:0, MUFA, C18:1c11, Mn, Zn,

Table 7. Analysis of correlation results.

\begin{tabular}{lcc}
\hline Variables & N rate & Mn rate \\
\hline $\mathrm{Cu}$ & -0.205 & -0.064 \\
$\mathrm{Fe}$ & 0.029 & $0.426^{*}$ \\
$\mathrm{Zn}$ & 0.054 & $0.378^{*}$ \\
$\mathrm{Mn}$ & $0.356^{*}$ & $0.391^{*}$ \\
$\mathrm{C} 16: 0$ & 0.029 & -0.164 \\
$\mathrm{C} 18: 0$ & -0.049 & -0.181 \\
$\mathrm{C} 18: 1 \mathrm{c} 9$ & -0.185 & -0.123 \\
$\mathrm{C} 18: 1 \mathrm{c} 11$ & -0.007 & -0.059 \\
$\mathrm{C} 18: 2$ & 0.138 & $0.245^{*}$ \\
$\mathrm{C} 18: 3$ & -0.026 & 0.131 \\
Saturated fatty acids (SFA) & 0.009 & $-0.248^{*}$ \\
Monounsaturated fatty acids (MUFA) & -0.168 & -0.115 \\
Polyunsaturated fatty acids (PUFA) & 0.124 & $0.246^{*}$ \\
C18:2/C18:3 ratio & 0.154 & 0.086 \\
\hline
\end{tabular}

*Correlation coefficients are significant at $\mathrm{p}<0.05$.

Figure 1. Variable plot. Location of load vectors to two principal components.

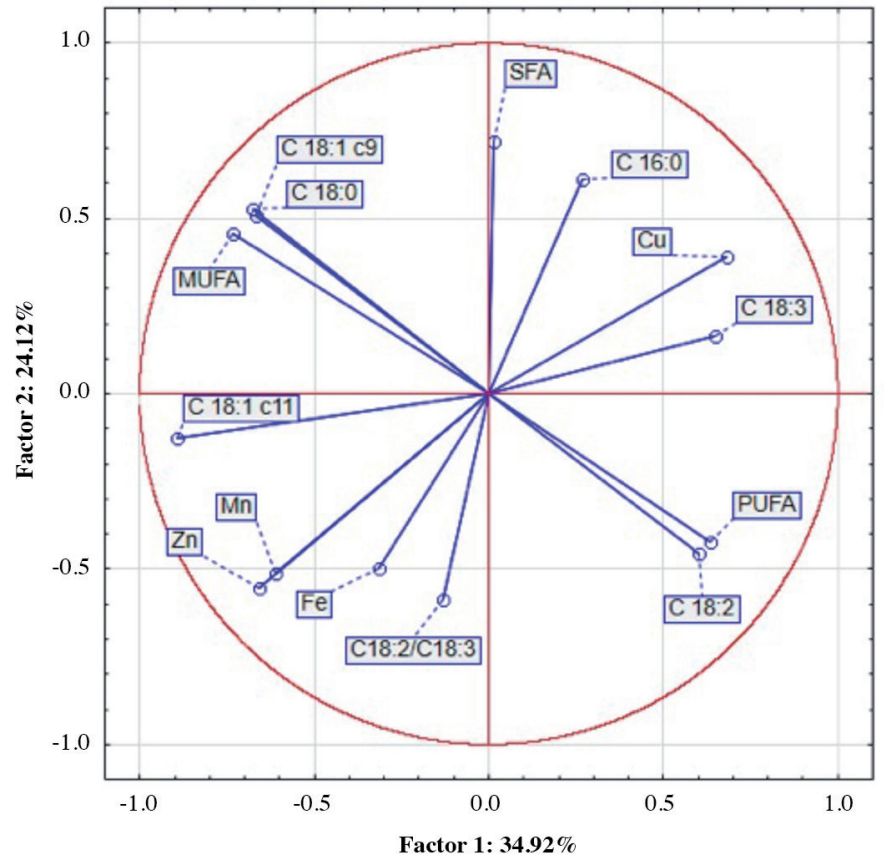

SFA: Saturated fatty acids; MUFA: monounsaturated fatty acids; PUFA: polyunsaturated fatty acids. 
$\mathrm{Fe}$, and $\mathrm{C} 18: 2 / \mathrm{C} 18: 3$. The second group consisted of SFA, $\mathrm{C} 18: 0, \mathrm{Cu}, \mathrm{C} 18: 3, \mathrm{C} 18: 2$, and PUFA. The vectors designating the $\mathrm{Zn}$ and $\mathrm{Mn}$ grain content were bound by a strong positive correlation. A positive correlation was also found between the $\mathrm{Cu}$ and $\mathrm{C} 18: 3$ content and between the $\mathrm{Fe}$ content and the $\mathrm{C} 18: 2 / \mathrm{C} 18: 3$ ratio. Negative correlations were observed between the $\mathrm{Cu}$ content vs. Mn and $\mathrm{Zn}$ content (strong negative correlations) and Fe content (negative correlation). This indicates the antagonistic effect of $\mathrm{Cu}$ with $\mathrm{Fe}, \mathrm{Zn}$, and $\mathrm{Mn}$, but only at a high disproportion between $\mathrm{Cu}$ and $\mathrm{Zn}$ ion contents (Rietra et al., 2017). The SFA direction vectors C16:0 and C18:3 were negatively correlated with the Mn and $\mathrm{Zn}$ wheat grain content.

The application of $200 \mathrm{~kg} \mathrm{ha}^{-1} \mathrm{~N}$ combined with $1.0 \mathrm{~kg} \mathrm{ha}^{-1} \mathrm{Mn}$ exerted varied effects on fatty acid composition and micronutrient content in wheat grain compared with the remaining fertilizer treatments (Figure 2). The clusters formed by different fertilizer treatments were evaluated based on the distribution of objects in two-dimensional component space. Nitrogen applied at $150 \mathrm{~kg} \mathrm{ha}^{-1}$ without $\mathrm{Mn}$ and $\mathrm{N}$ applied at $150 \mathrm{~kg} \mathrm{ha}^{-1}$ combined with $1.0 \mathrm{~kg} \mathrm{ha}^{-1} \mathrm{Mn}$ had a similar influence on the analyzed parameters. The remaining fertilizer treatments had a similar position and exerted a similar influence on the evaluated quality attributes of wheat grain.

The projection of variables and objects onto the plane formed by the first two principal components is displayed in Figure 3. The application of $200 \mathrm{~kg} \mathrm{ha}^{-1} \mathrm{~N}$ combined with $1.0 \mathrm{~kg} \mathrm{ha}^{-1} \mathrm{Mn}$ and the application of $150 \mathrm{~kg} \mathrm{ha}^{-1} \mathrm{~N}$ alone were correlated with the C:18:0, C18:1c11, C18:1c9, and MUFA content in the grain. The application of $200 \mathrm{~kg} \mathrm{ha}^{-1} \mathrm{~N}$ combined with $1.5 \mathrm{~kg} \mathrm{ha}^{-1} \mathrm{Mn}$ was correlated with the $\mathrm{Fe}, \mathrm{Zn}$, and $\mathrm{Mn}$ grain content. The remaining fertilization treatments were correlated with the $\mathrm{C} 18: 3, \mathrm{C} 18: 2$, and PUFA content and the $\mathrm{C} 18: 2 / \mathrm{C} 18: 3$ ratio in grain.

Figure 2. Fertilization variants in the first two main components.

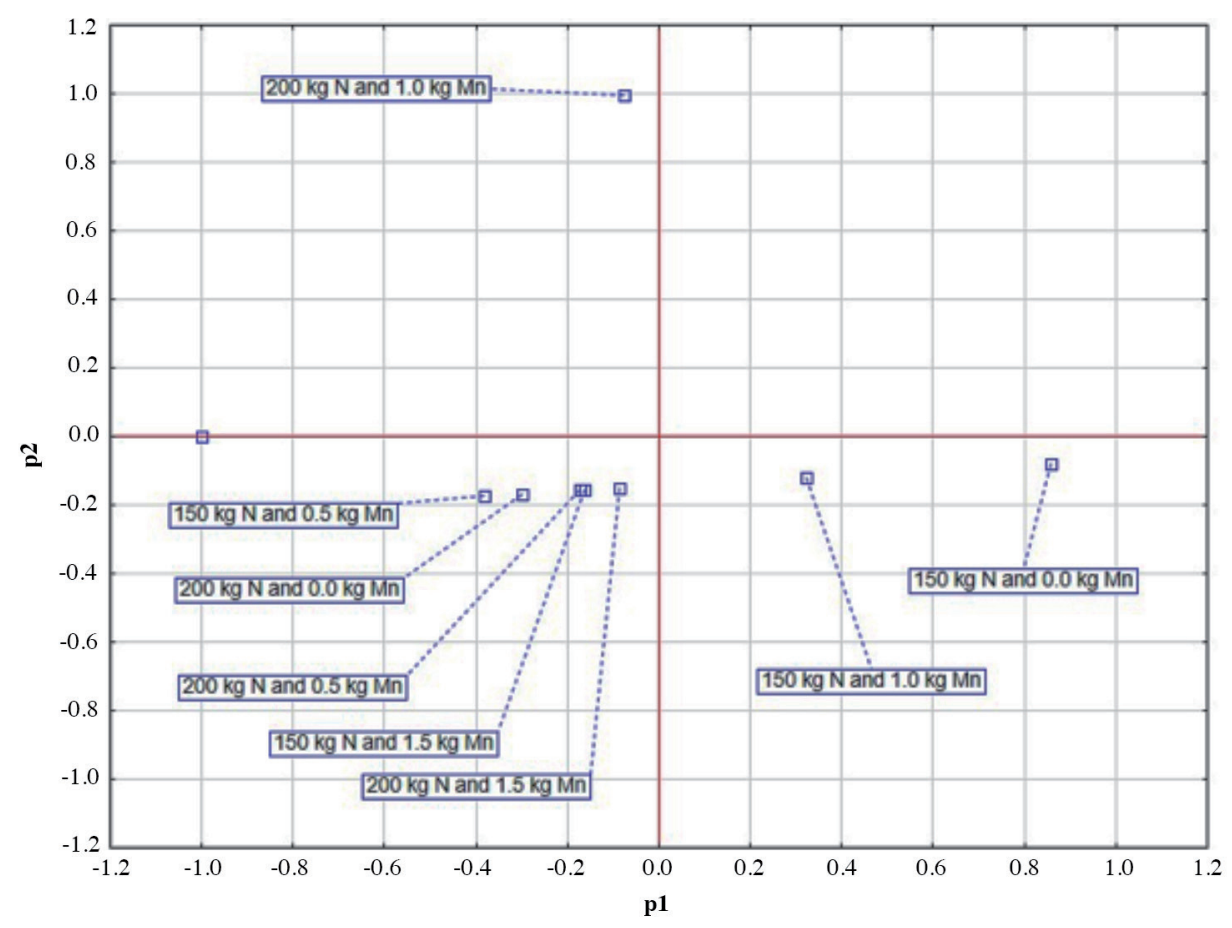


Figure 3. Projection of variables and objects on the plane of the first two main components.

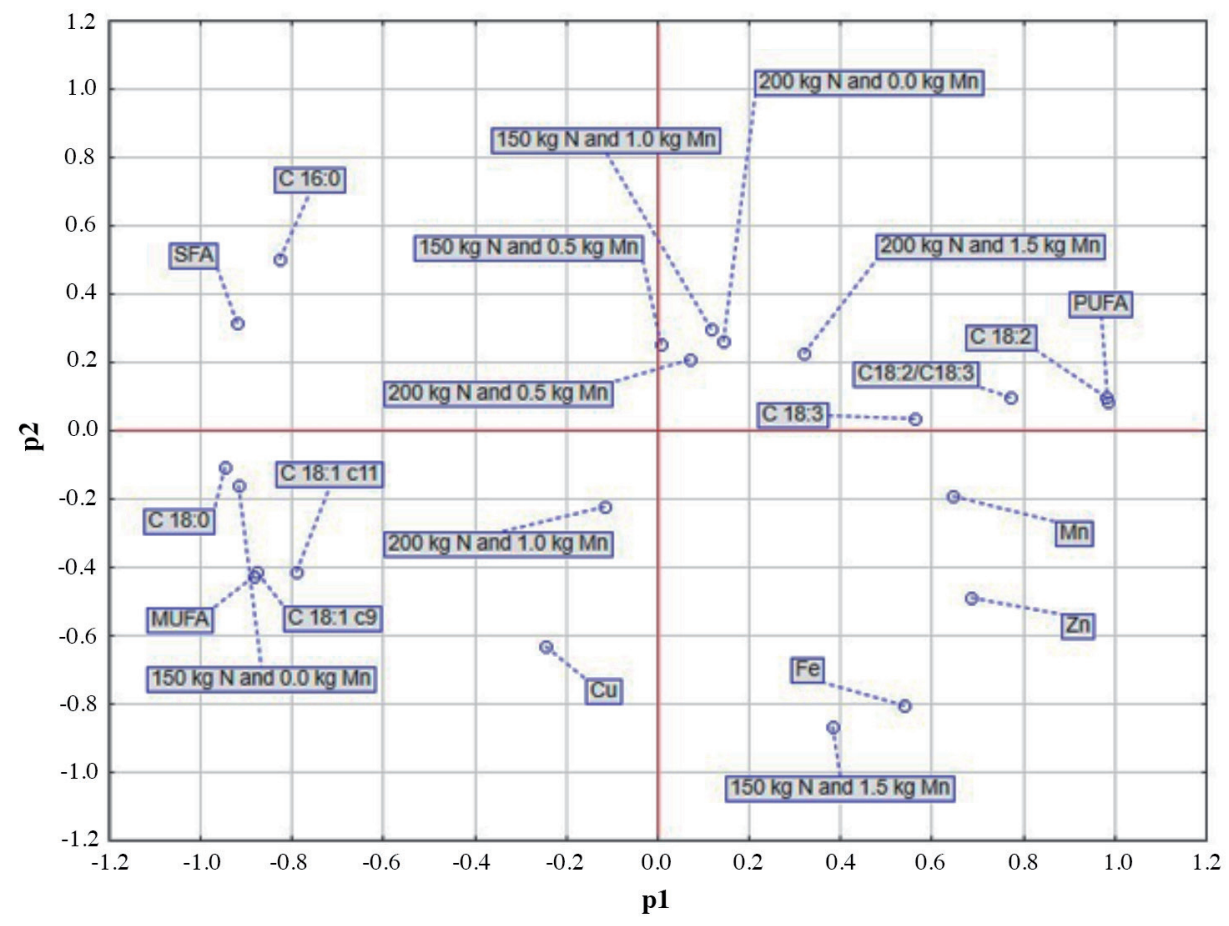

SFA: Saturated fatty acids; MUFA: monounsaturated fatty acids; PUFA: polyunsaturated fatty acids.

\section{CONCLUSIONS}

Weather conditions have a large impact on the effectiveness of $\mathrm{N}$ and $\mathrm{Mn}$ fertilization used and on the evaluated variables. An increase in the $\mathrm{N}$ fertilizer rate from 150 to $200 \mathrm{~kg} \mathrm{ha}^{-1}$ increased Mn content. Regardless of N fertilization, foliar application of $\mathrm{Mn}$ at $1.5 \mathrm{~kg} \mathrm{ha}^{-1}$ contributed to the greatest increase in the $\mathrm{Zn}$ and $\mathrm{Fe}$ grain content. The position of vectors of such properties as the $\mathrm{Zn}$ and $\mathrm{Mn}$ content in the grain is strong and positively correlated with each other. Negative correlations were found between the $\mathrm{Cu}$ content and $\mathrm{Mn}$ content as well as $\mathrm{Zn}$ and $\mathrm{Fe}$ in wheat grain. There is a positive correlation between the $\mathrm{Cu}$ content with $\mathrm{C} 18: 3$ and between the Fe content and the C18:2/C18:3 acid ratio. Vector variables of saturated fatty acids (SFA) and C16: 0 and C18: 3 acids are negatively correlated with the content of Mn and $\mathrm{Zn}$ and $\mathrm{Fe}$ in the wheat grain. Increased Fe, $\mathrm{Zn}$, and $\mathrm{Mn}$ content can be expected when using $150 \mathrm{~kg} \mathrm{ha}^{-1} \mathrm{~N}$ and $1.5 \mathrm{~kg} \mathrm{ha}^{-1}$ $\mathrm{Mn}$, and $\mathrm{Cu}$ using $150 \mathrm{~kg} \mathrm{ha}^{-1} \mathrm{~N}$ (without $\mathrm{Mn}$ ) and $200 \mathrm{~kg} \mathrm{ha}^{-1} \mathrm{~N}$ and $1.0 \mathrm{~kg} \mathrm{ha}^{-1} \mathrm{Mn}$. Results indicated that the $\mathrm{N}$ fertilizer application at $200 \mathrm{~kg} \mathrm{ha}^{-1}$ used in the present study beneficially affected polyunsaturated fatty acid (PUFA) content in the winter wheat grain and can therefore be used to obtain raw material with increased nutritional value. The human organism does not synthesize PUFA, and they must be taken with food (or supplements) and plant origin food such as winter wheat grain that can also be a good source because it contains more than $60 \%$ PUFA.

\section{ACKNOWLEDGEMENTS}

The project was financially supported by the Minister of Science and Higher Education through the program entitled "Regional Initiative of Excellence" 2019-2022, Project Nr 010/RID/2018/19, amount of funding 12.000.000 PLN. 


\section{REFERENCES}

Candela,C.G., Bermejo López,L.M., and Kohen, V.L. 2011. Importance of a balanced omega 6/omega 3 ratio for the maintenance of health. Nutritional recommendations. Nutrición Hospitalaria 26(2):323-329. doi:10.1590/S0212-16112011000200013.

Cequier-Sánchez, E., Rodríguez, C., Ravelo, A.G., and Zárate, R. 2008. Dichloromethane as a solvent for lipid extraction and assessment of lipid classes and fatty acids from samples of different natures. Journal of Agricultural Food Chemistry 56(12):4297-4303. doi:10.1021/jf073471e.

Ciolek, A., Makarska, E., and Wesolowski, M. 2012. Content of selected nutrients in wheat, barley and oat grain from organic and conventional farming. Journal of Elementology 17(2):181-189. doi:10.5601/jelem.2012.17.2.02.

Curtin, D., Martin, R.J., and Scott, C.L. 2008. Wheat (Triticum aestivum) response to micronutrients (Mn, Cu, Zn, B) in Canterbury, New Zealand. New Zealand Journal of Crop and Horticultural Science 36(3):169181. https://doi.org/10.1080/01140670809510233.

Diatta, J.B., and Grzebisz, W. 2006. Influence of mineral fertilizer nitrogen forms on heavy metals mobility in two soils. Polish Journal of Environmental Studies 15(2):56-62.

Diaz, C., Lemaitre, T., Christ, A., Azzopardi, M., Kato, Y., Sato, F., et al. 2008. Nitrogen recycling and remobilization are differentially controlled by leaf senescence and development stage in Arabidopsis under low nitrogen nutrition. Plant Physiology 147(3):1437-1449.

Erenoglu, E.B., Kutman, U.B., Ceylan, Y., Yildiz, B., and Cakmak, I. 2011. Improved nitrogen nutrition enhances root uptake, root-to-shoot translocation and remobilization of zinc ( $\left.{ }^{65} \mathrm{Zn}\right)$ in wheat. New Phytologist 189(2):438-448. doi:10.1111/j.1469-8137.2010.03488.x.

Escarnot, E., Jacquemin, J.M., Agneessens, R., and Paquot, M. 2012. Comparative study of the content and profiles of macronutrients in spelt and wheat, a review. Biotechnology, Agronomy, Society and Environment 16(2):243-256.

Fernández, V., and Brown, P.H. 2013. From plant surface to plant metabolism: the uncertain fate of foliar applied nutrients. Frontiers in Plant Science 4:289. doi:10.3389/fpls.2013.00289.

Fernando, D.R., Woodrow, I.E., Baker, A.J.M., and Marshall, A.T. 2012. Plant homeostasis of foliar manganese sinks: specific variation in hyperaccumulators. Planta 236(5):1459-1470. doi:10.1007/s00425-012-1699-6.

Jarecki, W., Buczek, J., and Bobrecka-Jamro, D. 2017. Response of spring wheat to different soil and foliar fertilization. Journal of Central European Agriculture 18(2):460-476. doi:10.5513/JCEA01/18.2.1919.

Jaskulska, J., Jaskulski, D., Galezewski, L., Knapowski, T., Kozera, W., and Wacławowicz, R. 2018. Mineral composition and baking value of the winter wheat grain under varied environmental and agronomic conditions. Journal of Chemistry 2018:5013825. https://doi.org/10.1155/2018/5013825.

Konopka, I., Grabinski, J., Skrajda, M., Dabrowski, G., Tanska, M., and Podolska, G. 2017. Variation of wheat grain lipid fraction and its antioxidative status under the impact of delayed sowing. Journal of Cereal Science 76:56-63. https://doi.org/10.1016/j.jcs.2017.05.013.

Kutman, U.B., Yildiz, B., and Cakmak, I. 2011. Effect of nitrogen on uptake, remobilization, and partitioning of zinc and iron throughout the development of durum wheat. Plant and Soil 342(1-2):149-164. https://doi.org/10.1007/s11104-010-0679-5.

Lambers, H., Hayes, P.E., Laliberté, E., Oliveira, R.S., and Turner, B.L. 2015. Leaf manganese accumulation and phosphorusacquisition efficiency. Trends in Plant Science 20(2):83-90. https://doi.org/10.1016/j.tplants.2014.10.007.

Levant, B., Zarcone, T.J., and Fowler, S.C. 2010. Developmental effects of dietary n-3 fatty acids on activity and response to novelty. Physiology \& Behavior 101(1):176-183. doi:10.1016/j.physbeh.2010.04.038.

Liñero, O., Cornu, J.Y., de Diego, A., Bussiere, S., Coriou, C., Thunot, S., et al. 2018. Source of Ca, Cd, Cu, Fe, K, Mg, Mn, Mo and $\mathrm{Zn}$ in grains of sunflower (Helianthus annuus) grown in nutrient solution: root uptake or remobilization from vegetative organs? Plant and Soil 424(1-2):435-450. https://doi.org/10.1007/s11104-017-3552-y.

Narwal, R.P., Dahiya, R.R., Malik, R.S., and Kala, R. 2012. Influence of genetic variability on zinc, iron and manganese responses in wheat. Journal of Geochemical Exploration 121:45-48. https://doi.org/10.1016/j.gexplo.2012.06.006.

Page, V., and Feller, U. 2015. Heavy metals in crop plants: Transport and redistribution processes on the whole plant level. Agronomy 5(3):447-463. doi:10.3390/agronomy5030447.

Pahlavan-Rad, M.R., and Pessarakli, M. 2009. Response of wheat plants to zinc, iron, and manganese applications and uptake and concentration of zinc, iron, and manganese in wheat grains. Communications in Soil Science and Plant Analysis 40(78):1322-1332. https://doi.org/10.1080/00103620902761262.

Pataco, I.M., Lidon, F.C., Ramos, I., Oliveira, K., Guerra, M., Pessoa, M.F., et al. 2017. Biofortification of durum wheat (Triticum turgidum L. ssp. durum (Desf.) Husnot). grains with nutrients. Journal of Plant Interactions 12(1):39-50. https://doi.org/10.1080/17429145.2016.1278049.

Persson, D.P., Hansen, T.H., Laursen, K.H., Schjoerring, J.K., and Husted, S. 2009. Simultaneous iron, zinc, sulfur and phosphorus speciation analysis of barley grain tissues using SEC-ICP-MS and IP- ICP-MS. Metallomics 1(5):418-426. doi:10.1039/b905688b.

Rajasekar, M., Udhaya Nandhini, D., and Suganthi, S. 2017. Supplementation of mineral nutrients through foliar spray-A review. International Journal of Current Microbiology and Applied Sciences 6(3):2504-2513.doi:doi.org/10.20546/ijcmas.2017.603.283. 
Rietra, R.P., Heinen, M., Dimkpa, C., and Bindraban, P.S. 2017. Effects of nutrient antagonism and synergism on yield and fertilizer use efficiency. Communications in Soil Science and Plant Analysis 48(16):1895-1920. https://doi.org/10.1080/00103624.2017.1407429.

Salama, Z.A., Youssef, M.A., Taie, H.A., and El-Baz, F.K. 2015. Increasing omega 6, omega 9 fatty acids and oil contents in black sesame seed by biofertilizer and micronutrients application. International Journal of Pharmaceutical Sciences Review and Research 31(1):256-261.

Sathiyavani, E., Prabaharan, N.K., and Surendar, K.K. 2017. Role of mineral nutrition on root growth of crop plants - A review. International Journal of Current Microbiology and Applied Sciences 6(4):28102837. https://doi.org/10.20546/ijcmas.2017.604.324.

Shi, R., Zhang, Y., Chen, X., Sun, Q., Zhang, F., Römheld, V., et al. 2010. Influence of long-term nitrogen fertilization on micronutrient density in grain of winter wheat (Triticum aestivum L.) Journal of Cereal Science 51(1):165-170. https://doi.org/10.1016/j.jcs.2009.11.008.

Smith, E.G., Janzen, H.H., and Ellert, B.H. 2018. Effect of fertilizer and cropping system on grain nutrient concentrations in spring wheat. Canadian Journal of Plant Science 98(1):125-131. https://doi.org/10.1139/cjps-2017-0079.

Socha, A.L., and Guerinot, M.L. 2014. Mn-euvering manganese: the role of transporter gene family members in manganese uptake and mobilization in plants. Frontiers in Plant Science 5:106.

Stepien, A., and Wojtkowiak, K. 2016. Effect of foliar application of Cu, Zn, and Mn on yield and quality indicators of winter wheat grain. Chilean Journal of Agricultural Research 76(2):220-227. https://doi.org/10.4067/S0718-58392016000200012.

Stepien, A., and Wojtkowiak, K. 2019. Evaluation of the effect of different levels of nitrogen and manganese fertiliser on the yield, macronutrient content and technological properties of winter wheat. Journal of Elementology 24(2):661-675. doi:10.5601/jelem.2018.23.4.1706.

UNE. 2015. UNE-EN ISO 12966-1:2015. Animal and vegetable fats and oils - Gas chromatography of fatty acid methyl esters. Part 1. Guidelines on modern gas chromatography of fatty acid methyl esters (ISO 12966-1:2014). Asociación Española de Normalización (UNE), Madrid, España.

Waters, B., Uauy, C., Dubcovsky, J., and Grusak, M. 2009. Wheat (Triticum aestivum) NAM proteins regulate the translocation of iron, zinc, and nitrogen compounds from vegetative tissues to grain. Journal of Experimental Botany 60(15):4263-4274. doi:10.1093/jxb/erp257.

Wojtkowiak, K., Stepien, A., Pietrzak-Fiecko, R., and Warechowska, M. 2018. Effects of nitrogen fertilisation on the yield, micronutrient content and fatty acid profiles of winter wheat (Triticum aestivum L.) varieties. Journal of Elementology 23(2):483-495. doi:10.5601/jelem.2017.22.3.1524.

WRB. 2014. World reference base for soil resources 2014. World Soil Resources Report Nr 106. FAO, Italy, Rome.

Zeidan, M.S., Manal, F., and Hamouda, H.A. 2010. Effect of foliar fertilization of Fe, Mn and Zn on wheat yield and quality in low sandy soils fertility. World Journal of Agricultural Sciences 6(6):696-699. 